\title{
Religion, Ethnicity, and Race in Finnish Legal Cases on Insults against Religion
}

TUOMAS ÄYSTÖ

University of Turku

\begin{abstract}
This article examines religious insults and related legal practice in Finland during the 21st century. It investigates how the Office of the Prosecutor General, the courts, and defendants construct the category of religion - which is the object of special protection - and how discourses on ethnicity and race play a role in this process. It is found that the language of both officials and defendants is affected by the lay discourse in Finnish society. This includes the decline of the importance of the formal category of religion found in the letter of the law and the increasing importance of the popular category. It is also argued that while being part of the established religion discourse improves the chances of benefiting from religious insult legislation, the said law is found to be a relatively ineffective avenue for groups seeking justice in the context of speech or actions considered religiously offensive. More generally, the article demonstrates that the discursive study of religion can benefit from a perspective in which categories such as ethnicity and race, which often intersect with the category of religion in social practice, are incorporated into the analysis.
\end{abstract}

Keywords: religion, ethnicity, race, Finland, religious insult, blasphemy, Islam

The idea that 'Islam is not a race' is frequently heard. It has been invoked in Finland by the journalist Tuomas Enbuske (2015), the anti-immigration politician Jussi Halla-aho (2010), and in the international arena by Richard Dawkins (2015) and Ayaan Hirsi Ali (Brockes 2010). It usually seeks to challenge the equation of anti-Islamic ideas or criticism of Islam with racism by demarcating Islam within the sphere of 'religion' rather than 'race'. This well exemplifies first, the importance of classification and second, that race and religion appear in some way connected in contemporary Western thinking. However, this article's goal is neither to argue that Islam is in fact a 'race' nor to define these terms somehow differently, but to examine how various ways of constructing, distinguishing, and conflating such categories are used by Finnish officials and defendants in certain criminal cases, and to what ends. 
The law on which this article focuses, the breach of the sanctity of religion (henceforward the BOSR), states that a person who 'for the purpose of offending, publicly defames or desecrates what is otherwise held to be sacred by a church or religious community, as referred to in the Act on the Freedom of Religion [...] shall be sentenced for a breach of the sanctity of religion to a fine or to imprisonment for at most six months'. ${ }^{1}$ This formulation came into effect in 1998, and there have since been about twenty guilty verdicts. This is a small number compared to many other crimes, but Finland, with Germany, Poland, Greece, and Italy, is among the most active in Europe in applying religious insult or blasphemy legislation (Koltay \& Temperman 2017). The law and its application have also attracted relatively significant media and popular attention in Finland.

Most previous research on religious insult and blasphemy in Finland has been historical (Olli 2008; Arminen 1999; Ketola 1995) or legal (Henttonen et al. 2015; Neuvonen 2012; Saarela 2011; Gozdecka 2009) ${ }^{2}$ in its orientation. In the field of the study of religion Äystö (2017a; 2017b; 2017c) has previously analysed some of the Finnish religious insult cases and the political discussion from which it originates. The Finnish religion discourse has previously been examined especially by Teemu Taira (2010; 2015), Titus Hjelm (2014), and Marcus Moberg et al. (2015). Ethnicity and race as socially constructed phenomena have received especial attention from sociologists and scholars of gender studies in Finland (see Keskinen 2013; 2014; Lepola 2000; Seikkula 2015; Toivanen 2014).

This article examines how, in the case of religious insults, Finnish officials and defendants construct 'religion' and, in connection with it, 'race' or 'ethnicity', and act on these constructions. These themes are significant because the category of religion is a central tool in the organisation of a modern Western society (Beckford 2003, 193-198; Taira 2016, 125f.), officials wield considerable power in this process, and religious insult in particular (often paired with freedom of speech questions) is one of the recurring themes of the current Finnish - and European - public discussions on the 'multireligious' or 'secular' society (Koltay \& Temperman 2017, 1-9). Discourses on ethnicity and race were incorporated into the analysis for empirical reasons:

1 The section also states that a person who 'publicly blasphemes against God [...] by making noise, acting threateningly or otherwise, disturbs worship, ecclesiastical proceedings, other similar religious proceedings or a funeral' is convicted of the same crime. (See Criminal Code of Finland, Section 10 of Chapter 17.) However, since all known BOSR cases utilise only the part of the section quoted in the body text above, this article will also focus on that part.

2 However, the BOSR is not the main focus of the cited legal scholars, but is assessed alongside questions of the freedom of religion or ethnic agitation. 
they were so abundant in the data that it was necessary to consider them to grasp the functioning of the category of religion - the focus of this article.

The article's main contribution to the study of religion is to offer an empirical account of contemporary religious insult law in Finland. The law crucially involves the category of religion and thus well exemplifies how the official language usage affecting society works with and uses the category of religion. The text also contains relevant points for those interested in hate speech, racism, and related discourses in Finland, because defendants' language is also examined. More generally, the article supports the idea that the discursive study of religion benefits from the study of categories close to 'religion' in the data, here meaning 'ethnicity' and 'race'. It is also an example of a non-legal and non-theological study of blasphemy law - a type of law surprisingly active (still applied in several countries) in today's Europe - representing a less explored avenue in which societal contexts, interests, and power relationships are emphasised instead of the more common normative questions (that is, whether blasphemy should be criminalised).

In investigating the cases, the article argues that the formal category of religion defined in the BOSR section is partly replaced by the category of religion originating from the lay religion discourse in Finnish society. Officials draw from established and popular ways of constructing religion in favour of their institutional discourse, essentialising and reifying religions in the process. This mirrors, it is argued, the ways in which defendants approach religion: in a general sense and rarely with specific registered communities in mind. This discursive practice results in the BOSR, as a legal instrument, appearing mainly to grant protection to well-known and established groups. However, since the law is relatively unpopular in the legal community and applied relatively infrequently, it is not a very effective avenue for those seeking justice, even for such groups. When crimes themselves are examined, it becomes clear that discourses on religion, ethnicity, and race are entangled. Defendants often succeed in attacking ethnic groups by criticising religion. This is connected with the ways in which 'Muslim', for example, is a racialising term in Finnish, associated primarily with non-white immigrants. The article continues with an examination of the ways in which officials tackle this categorical entanglement. In many cases another section of the criminal code - that dealing with ethnic agitation - appears to cover the primary crime, and the BOSR (less popular in the legal community and less supported by international law) may also be applied. Although there is an overlap between these two sections, the key 
difference is that the ethnic agitation section is used to protect 'groups of people', while the BOSR mainly concerns the protection of the 'religious sacred'. The category of 'sacred', then, emerges as the key distinguishing feature of the BOSR.

This article is organised as follows. Its methodology and data are described in the next section, followed by a section introducing the examined legal cases more thoroughly. The first analytical section then generally addresses officials' language in the category of religion: how it conforms to the lay religion discourse; how it relies on essentialism; and what these details entail. The second section addresses defendants' language concerning religion, race, and ethnicity: how it relates to broader societal discourses; and how this connects to the actions of officials. The third section returns to officials, considering how they construct the differences between religion, race, and ethnicity and what this means for legal practice. The findings are summarised in the concluding chapter, alongside a brief consideration of the article's broader implications.

\section{Methodology and data}

The data for this study consists of eleven cases handled by the Office of the Prosecutor General (henceforth the OPG) and ten cases decided by the Finnish courts between 1999 and 2017. The documents, twenty-six in total, were obtained directly from officials. The data does not contain all the Finnish BOSR cases from the period. This stems primarily from the practical difficulties in obtaining documents from officials and general transparency issues with the Finnish legal system. ${ }^{3}$ Thus, the article works with merely a sample of legal practice and the examined cases are described below. However, the sample is not random: the data contains all the well-known cases (to the general public and to the legal community) and several less well-known ones as supporting material. This is sufficient for the purposes of discourse analysis, which aims to examine officials' and defendants' language use in relation to the prevailing societal discourses. The aim is not to offer a comprehensive survey of case law.

The article uses a constructionist approach (Burr 2003, 1-9). It examines discourses - 'ways of referring to or constructing knowledge about a particular topic of practice' (Hall 1997, 3) - on religion, ethnicity, and race in the material. Instead of viewing legal documents as data reflecting reality, it

3 Difficulties in legally obtaining public documents are well documented with Finnish officials in general (Koski 2011) and legal officials in particular (Sutela 2016, 59; Kainulainen 2015). 
analyses how a version of reality is constructed, what is done on that basis, and what these constructions entail (Conley \& O'Barr 2005, 6-9).

The core of the methodology stems from the discursive study of religion (see Stuckrad \& Wijsen 2016; Moberg 2013; Wijsen 2013). More specifically, the approach resembles that applied by Taira $(2013 ; 2016)$ and Owen and Taira (2015), who have highlighted the methodological focus on the category of religion as an item of discourse and an emphasis on context-weighted analyses instead of nuanced linguistics. Here, discourse analysis is best conceived as a methodological framework. Rather than assuming what constitutes religion beforehand (i.e. an analytical definition of religion), the study concerns how the category of religion is constructed in the data. One can then begin to analyse which interests are advanced via particular uses of the category of religion, the kind of power relationships they reflect, and their ramifications.

Interpretations in the analysis unavoidably depend on the sociocultural knowledge (for example, viewing a certain expression as a racial slur; see Jokinen et al. 2016, 39) of the researcher, who, in this instance, analyses material from his home country written in his first language. In other words, discourse analysis is not about isolated texts but texts read in a cultural and societal context, which requires knowledge of that context. The researcher identifies and names discourses, but the core methodological claim is that there are patterns in constructing certain categories which are often referenced using terms like 'religion', and the analysis seeks to show how they function in the data and how they relate to broader societal practices.

Of course, the understanding of 'religious insult' depends on the definition of 'religion'. Beckford states that the notion of religion is 'constructed and used for all kinds of purposes by [...] institutions of law, the State, the mass media, school education, health authorities and so on' (Beckford 2003, 18), and that disputes concerning what counts as 'religion' have recently increased (Beckford 2003, 1). Hughes $(2017,309)$ argues that in liberal democracies it is specifically the courts that increasingly determine what is to be considered 'religious' - referring to various legal rulings and norms that regulate matters connected with 'religion'. It is generally well established that judges and other officials are often influenced by prevailing societal (Richardson 2000, 124-5; Ruuskanen 2006, 47-53) as well as their institutional discourses, but this needs to be treated as a possibility, not an assumption, in research.

The examination of the category of religion in this study is also supplemented by analyses of the discursive construction of 'race' and 'ethnicity'. 
According to Nye (2018) both religion and race are key categories for organising and governing differences in contemporary Western society. In the Finnish context the most cited examples of racialising speech about religion concern Islam and Muslims in the context of gender. For example, Islam is often described as a force oppressing Muslim women or Islamic veils are associated with radicalism and archaic values (Seikkula 2015, 27), and these themes are often associated specifically with non-white people. According to Seikkula (2015) this phenomenon is connected with the maintenance of a racialised boundary between the 'equal Finnish society' and 'others' that is bound by dated gender norms.

\section{The cases}

By law, the OPG handles cases related to the freedom of speech (Act on the Exercise of Freedom of Expression in Mass Media, para. 24), because they are seen as having a broad societal significance (VKSV:2015:4, p.1). ${ }^{4}$ Many, if not most, BOSR cases thus fall under their authority. However, if the case in question concerns, for example, a disturbance of religious ritual or actions other than language use, it can be handled by a district prosecutor (Kolehmainen 2009, 90; see Äystö 2017b). The OPG can also order a district prosecutor to present a case related to the freedom of speech in court (VKSV:2015:4). It is worth studying the decisions of the OPG, because the office is a central gatekeeper institution, wielding substantial legal power in deciding which cases move forward.

The letter of the law and the dominant interpretation do not require anyone actually to be offended, but actions committed need to be shown to be religiously offensive in a way even outsiders might grasp (HE 6/1997; see Henttonen et al. 2015, 78f.). However, there were other reasons for dropping these charges: the conclusion that the actions in question fell within the limits of the freedom of speech (Cases II and IV) or within the freedom of religion (Cases II and V); that the intention to offend, as required by the BOSR section, could not be demonstrated (Cases I, III, IV, and V); or that the actions in question targeted a person, not a religion per se (Case VI). The arguments are somewhat technical, but the legal criteria also require interpretations concerning the category of religion, basic and human rights (freedom of speech and freedom of religion), or the legal requirement involving the intention to offend.

4 See also <http://vksv.fi/fi/index/valtakunnansyyttajanvirasto/virastossakasiteltavatasiat.html $>$, accessed... 
The arguments in the prosecuted cases are quite concise. The prosecutor stated in all cases that the acts were committed publicly with a clear intention to offend, and that the actions defamed or desecrated something considered sacred by a religion. In the most recent cases, those of Halla-aho and Tynkkynen, the prosecutor also remarked on the societal repercussions: the statements would endanger the 'sanctity of religion in society' (Case $\mathrm{X}$ ) and would not 'advance the discussion' on important issues, but rather were 'bound to increase intolerance and prejudice' (Case XI).

Where the courts are concerned, it should be noted that District Courts initially handle criminal cases. Usually, any party may appeal against their decisions in the Court of Appeals, which may then grant a new hearing. Cases may also advance to the Supreme Court, which is the highest national stage, establishing judicial precedents. At the time of writing there were twenty-seven District Courts and five Courts of Appeal. Formally, all courts function relatively autonomously, bound only by the law.

Äystö (2017b) has previously examined Case XII in detail. From the perspective of the category of religion the case is interesting, since it confirms the letter of the law according to which the BOSR applies only to officially registered religious communities: the Court of Appeals dropped the BOSR charge in the final hearing because of this shortcoming. However, during the earlier stages of the process the police, the District Prosecutor, and the District Court considered Islam self-evidently a religion, so they decided to sidestep this formal detail and agreed that the actions constituted a BOSR. Äystö has argued that this, in addition to the language used by officials in general, demonstrated how their work was also influenced by the lay religion discourse, despite their formal reliance on the institutional discourse.

In the cases prosecuted by the OPG (all but two cases in Table 4) the courts agreed with the prosecutor's main arguments. This underlines the importance of the OPG's decisions. The basic facts are usually undisputed in BOSR cases (because the person did something on social media, and there is thus clear evidence). It is interesting that while one might assume that questions such as 'What is offensive?' or 'What is considered sacred by religion X?' should require some reflection, this is not usually evident in the documents. The main tone of the prosecutions and court convictions is thus strongly descriptive instead of analytical. For the most part they simply state, based on legal sources, that the perpetrator had publicly done something with the clear intention to offend, and that their actions were definitely insulting to the members of a religion. 


\section{The category of religion: formal background, conventional application}

As mentioned in the BOSR section, the law technically applies to a 'church or religious community, as referred to in the Act on the Freedom of Religion', which means it can apply to the Evangelical Lutheran Church, the Orthodox Church of Finland, and registered religious communities. Formal positions are thus important in the letter of the law. The churches mentioned are special cases with their own legislation stemming from Finland's history, whereas the registered religious community is a more recent legal category tailored for other groups that have successfully applied for it. Previously, Taira (2010) and Äystö (2017b) have examined the societal and legal meaning of this formal category in case studies.

As can be seen from Tables 1-4, all the cases concerned defamation against groups generally associated with Islam, Christianity, or Judaism, the best known 'religions' in Finland. ${ }^{5}$ According to the dominant legal interpretation (HE 6/1997, see Henttonen 2015, 79f.) the law formally applies to any registered religious community, of which there are currently 129 , most identifying as Christian or Islamic, but including groups identifying as Buddhist, Hindu, pagan, Mandaean, or Sikh. ${ }^{6}$ However, the emphasis on Islam in BOSR cases is clear. Of the sixteen cases examined eight were connected with Islam. Of the cases that went to court six out of ten were connected with Islam. The most publicly known BOSR cases (X, XII, and recently $\mathrm{XI}$ ) also concerned Islam, as did the only case $(X)$ considered by the Supreme Court. Äystö (2017b, 283-5; 2017c, 201) has previously argued that Islam's generally high visibility and the strongly politicised nature of the topic of immigration are key factors in Islam's prominence in hate speech cases. The Jyllands-Posten cartoon controversy in 2005 and 2006 is a probable factor in this prominence since the mid-2000s: the massive publicity activated both defamers, often invoking freedom of speech, and the officials who were supposed to combat them. The occasionally circulated idea that the BOSR is solely dedicated to the protection of Islam - or that Christianity is fair game - is, however, inaccurate.

It is worth examining official religion discourse - the language officials use about religion - in light of lay religion discourse - the language society

5 A well-known but problematic way of grouping these three is to talk of 'monotheistic', 'Semitic', or 'Abrahamic' religions. These concepts are known in Finland, particularly in the context of religious education, but they are not very commonly used in other public spheres.

6 Data on registered associations, including registered religious communities, is available at the Yhdistysnetti service, hosted by the Patent and Registration Office: $<$ http://yhdistysrekisteri.prh.fi $>$, accessed 1 January 2018. Further information on various groups is gathered by the Church Research Institute for the Religions in Finland service: <uskonnot.fi>, accessed 1 January 2018. 
uses about religion. ${ }^{7}$ Moberg et al. $(2015,59-62)$ state that the Evangelical Lutheran Church of Finland is the 'backdrop' and the 'blueprint' for the Finnish discourse on religion, reflecting the hegemonic status of institutional Christianity. They suggest the 'language available for religious and spiritual discourse in general still remains deeply connected to and influenced by Christian conceptual repertoires' (Moberg et al. 2015, 62). Taira $(2006,102 \mathrm{f}$.) has noted that there is substantial overlap between the Lutheran conception of religion and the general Finnish public religion discourse. However, the current media discourse on religion emphasises Christianity (especially Lutheranism) and Islam (Hokka et al. 2013; Niemelä \& Christensen 2013). Religion is therefore commonly associated with familiar features resembling Lutheranism or with familiar and visible 'world religions' like Islam.

Despite the formal emphasis on the official legal category of religion already mentioned, the question of whether the examined insults concerned a particular registered religious community rarely arises in BOSR cases. ${ }^{8}$ With the exception of four cases (I, II, XII, XVI) the case documents do not even mention a complainant (plaintiff): there is usually no actual church or registered religious community present as the concrete injured party. Although the dominant legal source states that the 'sacred is defined by the religious communities themselves, not by outsiders' (HE 6/1997; Henttonen et al. 2015, 78), the law does not require that anybody is actually offended at any point. Instead, officials examine the question of religious insults more generally: what is offensive in Islam, Christianity, or Judaism? They may use academic experts in some cases (III, V, VII, IX), but officials usually consider these questions by themselves.

The category of religion and its perceived subcategories (Islam, Christianity, and Judaism) are constructed in an essentialist manner by officials. ${ }^{9}$ For example, there are currently forty-six registered religious communities

7 The focus in this section is on the relationship between the lay religion discourse and the official religion discourse. The cases also occasionally feature discourses by academic religion experts such as Jaakko Hämeen-Anttila. However, they were not very prominent and were thus omitted from the analysis because of space constraints.

8 The only example where the registration status of a community was directly legally relevant was Case XII.

9 Essentialism is here understood following the description by philosophers Teresa Robertson and Philip Atkins (2018): 'Essentialism in general may be characterized as the doctrine that (at least some) objects have (at least some) essential properties.' In case of religion and law, as T. Jeremy Gunn (2003, 194) writes, 'whenever a legal definition is essentialist, it assumes that religion has one or more elements in common with all other religions' - that is, essentialism identifies the necessary elements for something to be X. By extension essentialism would also refer to a position according to which e.g. Christianity is constituted by certain essential properties, such as particular doctrines and practices. (For further discussion on essentialism and definitions of religion in law see Blevis 2016). 
identifying as Islamic. ${ }^{10}$ Empirically, these communities have diverse backgrounds and differing approaches to Islam (Martikainen 2008, 71-6; Pauha et al. 2017). In the studied legal practice, however, these differences are not meaningful, as Islam is mostly described as a single entity in the world with certain sacred things and values. This is often evident in the ways in which the courts assess the defamatory nature of actions:

The District Court considers the examined images to be very insulting because the prophet Muhammad is considered sacred according to the prevailing understanding in the Islamic religion. The statement by the professor of Arabic and Islamic Studies, Jaakko Hämeen-Anttila, strongly supports this interpretation. [...] They [the defendants] must have understood that the pictures they published were likely to insult and defame things considered sacred by Muslims (Case IX, R 07/3284). ${ }^{11}$

Reflecting the same essentialism, 'Islam' as such is often likened to a 'religious community', the formal category described in law: instead of talking of distinguishable communities properly registered as the letter of the law requires, officials often simply talk of 'Islam' as a distinguishable 'religious community' as meant by the law. The prosecutor argued as follows:

According to the Freedom of Religion Act a religious community refers to the Evangelical Lutheran Church, the Orthodox Church, and to the registered religious communities registered as described in Chapter 2 of the said Act. The Finnish Patent and Registration Office handles decisions on registrations and maintains the Register of Associations. Several Islamic communities are listed on the register of the said office. It is therefore clear that Islam is a religious community as referred to in the [BOSR] corpus delicti (Case III, R 06/11).

In another case the court described Judaism - or 'the religion of the Jews', as they called it - as a single and unitary entity:

The defendant defames the religion of the Jews in many ways. He describes the Talmud, which contains the extensive rabbinic tradition, as considering only Jews to be human and commanding Christians and other non-Jews to

10 Data from the Yhdistysnetti service $<$ http://yhdistysrekisteri.prh.fi>, accessed 1 January 2018. The criterion for this identification is that registered religious communities have 'Islam' or 'Muslim' in their name, or explain their identification on their website. However, there are also more than 120 groups that have 'Islam' or 'Muslim' in their association's name, but are registered as regular associations (Pauha et al. 2017, 105).

11 All citations from the data, unless otherwise stated, are translated by the author. 
be killed. [...] Based on them [the statements], ' $\mathrm{A}$ ' clearly intended to cause similar resentment of the Jews among his readership as he himself has. This also constitutes a defamation of the religion of the Jews with the intention to offend (Case VII, R 03/1129).

More generally, official language relies strongly on the Finnish lay understanding of religion (Moberg et al. 2015, 59-62; Taira 2006, 102f.; see also Smith 2004, 377). The characteristics of 'religion' in the examined material appear to be holy books, certain core practices and dogma, sacred figures such as a prophet or a God, sacred buildings as the sites of practice, a substantial number of followers, and organisation into communities, and involve especially sensitive sentiments (or at least more sensitive than political sentiments, for example). These findings fit the previous descriptions of the Finnish public religion discourse quite well (Moberg et al. 2015, 59-62).

Although the official institutional discourse provides a technical way to define religion (properly registered communities and the two state churches), the lay discourse trumps it as the key ingredient for constructing religion. In the studied material 'religions' refers primarily to the best known family of religions: Christianity (especially the Lutheran and other major established churches), Judaism, and Islam. They are reified (made into things found in the world) and essentialised: they are assumed to have a unified set of core dogmas, practice, and sacred things.

As the religion discourse used is essentialist in its nature, the BOSR becomes a relatively crude instrument, because it focuses largely on the 'central features' of 'established religions'. If the aim of the law is to protect the sacred things of registered groups effectively, it is likely that they should be viewed in a more nuanced way. Furthermore, as is the case with all discursive constructions, this essentialism offers a partial and selective view and knowledge of the object at hand ('religions'). As has been established, officials draw from the lay religion discourse. The prevailing public language concerning religions is largely moulded by the majority, and it thus also reflects the power relationship between majority and minority groups.

An important factor in this reliance on the lay discourse is that the examined offenders usually do not target particular religious communities either, but also speak about Christianity, Islam, or Judaism in a general sense. It is therefore challenging for officials to identify a single victim. Moreover, as has been mentioned, the letter of the law and its prevailing interpretation do not require that anybody is actually offended: the actions committed simply need to be demonstrated to be religiously offensive in a manner 
even outsiders can grasp (HE 6/1997; see Henttonen et al. 2015, 78f.). There appears in this sense to be a discontinuity between the definition of religion in the letter of the law and how it is described in actual legal practice. The created legal devices emphasising the formal category of religion and association-based identification fade into the background when the offences against religion investigated largely do not follow the same structure but speak of Christianity, Islam, or Judaism a great deal more generally. ${ }^{12}$ Thus, officials also resort to the same widely shared religion discourse as defendants, albeit using it for a very different purpose. The nature of the offences themselves (the fact that they do not usually target particular communities or churches, but Islam or Christianity in general, for example, instead), and the influence of the lay religion discourse, means that the formal category of religion becomes relatively insignificant in BOSR cases.

These observations raise questions about the consistency of the legal practice. In Case XII the defendants spattered animal blood on a mosque used by a certain community. The BOSR charge was dropped because the community in question was not registered as the law formally required (see $\ddot{A} y s t o ̈ ~ 2017 b)$. If one assumes the essentialist understanding of Islam that prominent in other court cases concerning it, is attacking a mosque ${ }^{13}$ with blood as generally offensive as attacks against the prophet Muhammad? There is a potential imbalance in the law: in cases where a link to a particular community is obvious (Cases I, II, XII, XVI) the requirement of registered status can be applied straightforwardly - and here unregistered status can be a concrete disadvantage (as Case XII shows) - but officials rarely pay such nuanced attention to religious associations in BOSR cases, because religions are discussed more generally.

As the category of religion and the related discourse used by officials so closely follows the dominant societal classifications, the obvious question is: who is omitted? As this is the reality of the 'religious landscape' constructed in the discourse, there is another imbalance: it is likely that lesser known groups that perhaps correspond less with these prototypical features of religion will need to play a considerably more proactive role if they feel targeted by an illegal insult. As Taira (2010) has shown, for example, features understood as unconventional may already be a disadvantage

12 However, the institutional religion discourse with its formal criteria is also influenced by the societally dominant discourse, as previously argued by Taira (2010) and Äystö (2017b).

13 As was the case here, most mosques in Finland are not purpose-built, but are regular apartments or similar spaces often unrecognisable as mosques to the average passer-by. 
when an association is processing its registration (see also Doe 2011, 112f.; Hjelm et al. 2018).

However, returning to the question of consistency, the legal scholar Jyrki Virolainen, commenting on Cases III and X in his personal blog, ${ }^{14}$ criticised the prosecutor's failure to establish why Halla-aho's verbal attack on the prophet Muhammad was prosecuted, while the republication of the Jyllands-Posten Muhammad cartoons was not. More generally, since the lay religion discourse is concerned mostly with Lutheranism and Islam, and there is a large range of discussions concerning them, an abundance of obviously hostile and potentially offensive statements circulates online. However, convictions in BOSR cases remain rare, and it is not always clear why one case is proceeded and another is not. A general assessment is therefore that the legal arena and the BOSR section, considered as it is to be a relatively obscure law, offer an ineffective route for anybody seeking to advance their interests amid hostile speech or actions, although belonging to the established religion discourse improves the odds. There is also something to be said about the roles of discourses on ethnicity and race, and about their relationship with the category of religion. These are tackled in the remaining sections.

\section{Religion, ethnicity, and race in the language of the perpetrators}

In most studied cases ethnic agitation was also considered alongside the BOSR, as can be seen from Tables 1-4. Ethnic agitation is described in Section 10 of Chapter 11 of the criminal code (concerning war crimes and crimes against humanity): 'A person who makes available to the public or otherwise spreads among the public or keeps available for the public information, an expression of opinion or another message where a certain group is threatened, defamed or insulted on the basis of its race, skin colour, birth status, national or ethnic origin, religion or belief, sexual orientation or disability or a comparable basis, shall be sentenced for ethnic agitation to a fine or to imprisonment for at most two years. ${ }^{15}$ This crime is viewed as more severe than the BOSR, having a harsher maximum

$14<$ http://jyrkivirolainen.blogspot.fi/2009/04/halla-ahon-syyte.html>, accessed 29 January 2018.

15 The law is also known as 'incitement to hatred', and this is its current formulation. There were slight modifications to the law in 1995 and 2011: for example, it has been widened to encompass other types of hate crimes besides racist ones, and an aggravated version of the crime was introduced (Henttonen et al. 2015, 39-41). The citation is from the Ministry of Justice's unofficial translation of the criminal code: http://www.finlex.fi/fi/laki/kaannokset/1889/en18890039.pdf (accessed 29 January 2018). 
punishment, and it is also applied more often (Henttonen et al. 2015, 39-60; see Illman 2005, 215-89).

In several cases concerning conviction for both ethnic agitation and the BOSR the committed actions reveal that the categories of religion, ethnicity, and race are often entangled for the perpetrators. For example, in Case XIII, the defendant wrote online:

[A Finnish derogatory term for Middle Eastern people] view women of the wrong faith as dogs. This is determined by their religion and by their genetic heritage. People of the wrong faith have no value in the eyes of [n-word], as they are only objects of sexual satisfaction (R 13/6335).

Likewise, in Case XIV the defendant had written:

These uncivilised animals should be sent back to their barbaric country, or preferably shot on sight. [...] Put them into aeroplanes without explanation, complaint, bureaucracy, and other bullshit, and make the next stop in some shitty country in Africa or the Middle East. [...] Why are people who have no cultural qualifications to adapt to a Western society willingly brought here just to live like parasites off the tax of decent people? Why must Swedish children, too, fear the barbarians who speak a foreign language, practise a foreign religion, have foreign customs, and hurt them (R 16/1796)?

In a third example (Case XI) the politician Sebastian Tynkkynen had written as follows (note, for example, that by 'Islam' he referred exclusively to recent immigrants from Africa and the Middle East, not to white converts or to the older Tatar population): ${ }^{16}$

Islam needs to be removed from Finland. A way of thinking cannot be banned, and this should never be done in a Western state like Finland that respects the freedom of speech. However, we can start to return those who have no reason to stay in our country at full speed. For example, the determined security status of Iraq, Afghanistan, and Somalia has changed, and we must strive to get people from these honour cultures back to their peers. [...] Of course, not all Muslims follow the dogmas of their prophet. However, social peace was destroyed by only a few strikes against the infidels, inspired by Muhammad. [...] The fewer Muslims we have, the safer we are (R 16/700).

16 A Tatar Muslim community of approximately a thousand people has been present in Finland since the late 19th century. 
Here, religion discourse mostly functions as a reference to unwanted people with an immigrant background. Terms considered racial or ethnic (racial slurs, references to African or Middle Eastern background) and terms considered religious (Muslim) in the examples are tightly connected and used to refer to the same group: non-white Muslim immigrants - an overlap of categorisations that might be called an 'intersection', as described by Kimberlé Crenshaw (1991).

Äystö (2017c) has previously examined the politician Jussi Halla-aho's well-known court case (Case X), in which the defendant claimed that the prophet Muhammad was a paedophile and Islam was therefore a paedophile religion, and also stated in the same text, that ' $[t]$ he robbing of people on the street and living off tax funds is a national, perhaps a genetic feature of the Somalis', one of the most visible Muslim groups in Finland. Halla-aho was convicted of both the breach of the sanctity of religion and ethnic agitation. Äystö (2017c) argued that since the category 'Muslim' is racialising in Finnish - it tends to communicate that the person in question is nonwhite - attacking Islam enabled Halla-aho to communicate more than one message, advancing his anti-immigration politics and criticising the official multicultural consensus. He was also able to provoke the reaction he desired from the officials, for which he had a pre-prepared political interpretative framework. ${ }^{17}$ His simultaneous attack on a specific group (Somalis), also composed mainly of Muslims, again highlighted the overlap of the Finnish discourses on religion, ethnicity, and race.

Similar observations concerning the intertwining of religion, ethnicity, and race can be made in Cases IX and X. It should be noted, however, that the above quotations were used by the courts to pass a verdict on ethnic agitation, not the BOSR. Although the discourses on ethnicity, race, and religion were clearly connected in the original statements, the officials distinguished the two crimes, one involving a crime against a 'group of people' and the other against 'religious sentiments' (see the next section).

In the three quotations above we can also identify several familiar discourses often utilised in either specifically anti-Islamic or anti-immigrant contexts (Keskinen 2012), or even in the standard Finnish media portrayals of Islam and Muslim immigrants (see Taira 2015, 161-83; Hokka et al. 2013). Among these are the discourses of the West and the rest (Hall 1992), civilisation versus barbarism (Hall 1992), securitisation (Kaya 2009; Marti-

17 As Halla-aho spells out in his personal blog, he intended to bait the officials into convicting him of the BOSR, thus, he maintains, demonstrating that officials pamper and protect Muslims in particular. The desired reaction was the conviction itself. 
kainen 2013a), and violence and excessive sexuality (Miles \& Brown 2003, 26-30). Gender and its link to racialised boundaries is a significant theme, as Muslim immigrants are here exclusively thought of as males posing a threat of sexual violence to Finnish women (see Keskinen 2013; Nagel 2003). At the same time Finland emerges as a religious, cultural, and racial formation - defined by Western civilisation, non-Islamic religion (Finnish Lutheranism specifically), certain customs, and whiteness - presented as fundamentally opposed to that of the Muslim immigrants. These details accord well with previous findings on Finnish nationalism and religion (Martikainen 2008, 66ff.; see Anttonen 2010, 146-59; Taira 2015, 181ff.), and especially on Finnishness and whiteness (Lepola 2000, 368-71; Keskinen et al. 2015; Seikkula 2015; Toivanen 2014).

In sum, speech about religion of course functions for defendants as a way to criticise a religion, but also often as a way to say hostile things about groups of a particular national or ethnic background or skin colour. This is closely connected with nation construction. Here, Finland is conceived of as a Lutheran country, and ideas of whiteness and particular cultural customs are also connected with it. The BOSR section, dedicated as it is to protecting religions from insults, therefore finds itself in a much more complex environment than lawmakers probably initially envisaged. The law stems from the more conventional modern Western discourse in which religion is often portrayed as a distinct and separate societal realm, and later also as a matter of choice. ${ }^{18}$ However, attacking Islam and Muslims enables attacks on broader groups in the discursive context. Critics may strategically claim, in referencing the modern notion about religion being a separate entity, that 'Islam is not a race', but separating discourses on religion, ethnicity, and race is complicated in many cases. How officials, nevertheless, pursue this challenge, is addressed next.

18 For the Western religion discourse and religion as a separate realm see Nongbri 2013, 7. José Casanova $(1994,213)$ has argued that there is a longer trend in which religion loses its compulsory institutional character and becomes voluntary, and once freedom of religion is established, all churches and religions become denominations - that is, choices. For the parliamentary background of the current BOSR law see Äystö 2017a. When the law was being formulated, many MPs considered religious emotions as requiring special protection (i.e. they were distinct from e.g. political emotions), while some argued that Christian vocabulary such as 'God' was best kept away from parliamentary politics and law (i.e. religious vocabulary should be kept separate from other realms). In turn, the constitutional law committee stated that the purpose of the BOSR was to protect public order and the freedom of religion (PeVL 23/1997). 


\section{Religion, ethnicity, and race in official language}

As 'religion' is also mentioned as a criterion for a group in the ethnic agitation section, it is important to note the legal differences between it and the BOSR section. The legal scholars Henttonen et al. $(2015,74)$ state that the ethnic agitation section seeks to protect people who might have religious convictions, not 'religions, religious customs or institutions' per se. However, the BOSR has a similar purpose: it is thought to protect the 'religious sentiments of people' and the 'sanctity of religion (or "peace concerning religion") in society', and 'not religion as such' (Henttonen 2015, 76; HE 6/1997). It is therefore admitted that these laws have some overlap in their interest in protection (Henttonen et al. 2015, 75-87). ${ }^{19}$

Concerning the definition of religion, an important difference between the ethnic agitation and BOSR sections is that while the BOSR works as a formal criterion for religious groups, the ethnic agitation section does not. Legal literature (that is, an unofficial but widely used legal source) only offers a very broad characterisation in the context of ethnic agitation: 'a religious group is basically composed of any group of people with the same religion, such as the Jews'. In turn, ethnic groups are described as 'groups of people with shared customs independent from nationality' or 'for example, the Roma people'. The term 'race' is considered problematic from the scientific perspective, but it is said to be maintained in the letter of the law because of its established meaning in everyday speech. It is noted that 'in practice, racial groups are composed of national and ethnic groups' (Henttonen et al. 2015, 51). It is quite clear that the legal understanding also draws from the lay discourse in this instance.

A partial explanation of the frequent co-occurrence of the ethnic agitation section alongside the BOSR in legal practice is that Finnish lawyers do not consider the BOSR itself to be very important. The legal trade magazine Juristikirje conducted a poll in June 2012 on which laws the Finnish jurists would most willingly abolish. The most popular answers were the unlawful use of narcotics and the breach of the sanctity of religion. Moreover, several legal scholars have argued that the BOSR section should be dropped and that religious groups could be protected like ethnic groups (see Saarela 2011; Nuotio 2009). In contrast, legal experts generally consider the ethnic agitation section significant and well supported by international law (see

19 A relevant examination, though one beyond the scope of this article, would be to address the cases in which the ethnic agitation section is used to protect a group considered 'religious' without invoking the BOSR (see Henttonen et al. 2015, 70ff.). 
Saarela 2011; Nuotio 2009). We may therefore assume that officials more readily advance cases in which there are reasons to suspect ethnic agitation, and that if the BOSR section can also be applied, this may be considered.

It is fitting that all the 'religions' included in the data - Christianity, Judaism, and Islam - have strongly ethnic or racial connotations in the lay religion discourse.$^{20}$ In Christianity, and Nordic Lutheranism in particular, this is connected with white Finnishness. ${ }^{21}$ As the court phrased it in a previously quoted passage, Judaism can be referred to as the 'religion of the Jews', an expression that emphasises the idea of Judaism as a religion of a particular ethnic or racial group. Islam, on the other hand, is often considered a religion of non-white immigrants. Working in such a discursive environment, officials are dealing with complex intertwinings of religion, ethnicity, and race from the outset. It is therefore to be expected that sections referencing 'religion', 'skin colour', and 'ethnicity' appear together frequently. The fact that the guilty verdicts concerning ethnic agitation examined here have involved either Islam or Judaism reflects both the discursive phenomenon in which 'the majority' (white Lutheran Finns) is not racialised or usually thought of as an ethnically similar group, and the legal aim to especially protect 'minorities' through such legislation (see Henttonen 2015, 50). ${ }^{22}$ Of course, it is also important to note that Jews and later Muslims, among other groups, have historically been targets of Finnish racism (see Puuronen 2011).

In a case the prosecutor decided to drop he evaluated Christianity-related cartoons as follows:

One can infer from pictures that the preliminary investigation was concerned that they communicated a message about Christianity and related doctrine. One cannot, however, infer that the pictures aim to incite hatred towards a group of people composed of members of the Christian churches (Case IV, R 07/2).

In another case the court decided that the defendant had attacked various groups:

20 Of course, similar observations can be made from other 'world religions' and their historical connection with certain populations. The abovementioned ones are relevant in the current Finnish religion discourse.

21 This is the case despite the fact that there is an increasing number of non-white Christians in Finland: for example, people with an Asian or African background. (Martikainen 2013b, 1-17.)

22 The quotation marks here aim to reflect that although the terms 'majority' and 'minority' sound like neutral demographic classifications, they nonetheless employ some constructed criteria by which they are recognised. 
A has made messages available to the public that defame and insult Muslims and people with African backgrounds and dark skin, which also threaten Muslims (Case XIII, R 13/6335).

These quotations capture the variation quite well. In all cases studied where both BOSR and ethnic agitation convictions were passed the 'group' under attack referred to skin colour (non-white), place of origin (African or Middle Eastern), or religion (Islam or Judaism).

From officials' perspective the legal distinction between crimes against 'religious sentiments' and 'societal peace concerning religion' (the BOSR) and crimes against a 'group' (ethnic agitation) is perhaps not especially difficult to make. An attack against the religious sacred is the key to the BOSR as it is applied today. 'The sacred' is the section's key distinguishing feature. The BOSR is exclusively invoked in cases where a 'sacred thing' (generally known and easily recognisable) of a 'religion' (one that is well known and already established as such) is attacked. Because of the current discursive connections or intersections it happens that such attacks on 'religious sentiments' often also employ discourses associated with 'race' and 'ethnicity', thus triggering the ethnic agitation section. This is similar to a case where lay religion discourse defendants employed guided officials to use the same discourse. Both officials and defendants share the basic sociocultural knowledge ${ }^{23}$ concerning the expressions considered offensive or racist, and both expressions are therefore legally controlled and politically useful, and thus often invoked.

To be clear, there is no direct equivalent in Finland of the racial and ethnic self-identification categories used, for example, by the US Census Bureau, by which the population is demographically and officially divided into races and ethnicities. Finnish official discourses on race and ethnicity are much subtler. Officials' main aim here is to combat racism against minorities, but they do this without established formal criteria for such groups: while there is an official list for registered religious communities, there is no such list for different ethnic groups. Thus, as was the case with the category of religion, officials perform their legal obligations by utilising the societally prevailing discourses on ethnicity and race, or more specifically, how these groupings are understood in everyday Finnish.

23 One should also note that all officials and defendants examined here were white Finns. 


\section{Conclusion}

It was argued above that there is a tension between the institutional religion discourse and the lay religion discourse prevailing in society in general. Formally, 'religion' is supposed to refer to registered religious communities and the Lutheran and Orthodox churches. However, an examination of the cases shows that since perpetrators utilise the lay religion discourse (in a hostile way), officials respond by mostly adopting the same religion discourse to combat actions deemed criminal. In brief, the formal category of religion has little significance in BOSR legal practice, because defendants construct religions in a more essentialist and general manner, and officials thus do so as well. The essentialist language renders the BOSR a crude tool that mainly enables the protection of the 'central features' of 'established religions' ${ }^{24}$ As has been described, these details are also problematic from the perspective of legal consistency, since a community's registered status may not always be relevant in certain cases. As a general conclusion, while it was noted that being a well-known and established 'religion' improves the odds, the BOSR is not a very effective route for any group seeking justice in the context of speech or actions considered hostile or offensive..$^{25}$

Continuing with the language of perpetrators, the article argued that discourses on religion, ethnicity, and race were tightly connected. The defendants often used terms like Muslim or racial slurs to refer effectively to the same group. Thus, speech perceived or claimed to be about religion can be racialising and serve broader agendas in the sociolinguistic context. In the examples the perpetrators' aim was to oppose non-white Muslim immigration. Defendants used discourses often associated with Islam in the West, including discourses of securitisation, violence, and excessive sexuality. As the BOSR relies on a more conventionally modern category of religion - religion as a separate realm in society - its application becomes complicated because defendants often mix language on religion, race, and ethnicity.

It is observed that the BOSR and ethnic agitation laws frequently cooccur, and this is primarily because of the entanglement of key categories

24 In other words, since officials apply essentialist language drawing on the lay religion discourse, the most well-known religions and features considered 'central' to them are most likely to be protected.

25 Expressed differently, since the total number of prosecutions and guilty verdicts is so low while hostilities towards religious groups are commonplace, the law is ineffective in delivering results from the perspective of religious communities. Furthermore, since the law has only managed to deliver results for Christian, Islamic, or Jewish groups, groups otherwise identifying or identified have an even lower chance of benefiting from the BOSR law. 
(religions, ethnicity, and race) and the secondary nature of the BOSR (it is applied alongside the more common ethnic agitation section if possible). Unlike perpetrators, officials aim to clearly distinguish crimes against religious sentiments (the BOSR) and groups of people (ethnic agitation), and the main element triggering the BOSR is an offence against a well-known 'religious sacred' thing. The 'sacred' is found to be the central defining element of the BOSR law as it is applied in legal practice and the key element by which it is distinguished from ethnic agitation.

Generally, this study shows that it can be beneficial to broaden the scope of analysis in the discursive study of religion with categories empirically connected with it. In this case the data directed the focus to the relationships between religion, ethnicity, and race. It was demonstrated that the category of religion often intersected with the categories of ethnicity and race. Religious insults and the related debate on freedom of speech generally present a good opportunity to examine contemporary societal conflicts. In studying these matters, a focus on the societal contexts and interests of the various stakeholders and the potential consequences of categorisations and other choices made is beneficial.

TUOMAS ÄYSTÖ is Doctoral Candidate of Comparative Religion in the University of Turku, Finland. E-mail: tjayst@utu.fi 
Bibliography

Data

Legislation

Criminal Code of Finland. 19.12.1889.

Preliminary work documents, Finnish parliament

PeVL 23/1997. Constitutional Law Committee statement on Government bill 6/1997.

HE 6/1997. Government bill regarding the renewal of legislation concerning crimes against the judicature, officials, public order, and sex crimes.

Office of the Prosecutor General

$\mathrm{R} 02 / 3$

R $05 / 8$

$3 / 27 / 05$

R 05/14

R 06/11

R $07 / 2$

R $08 / 10$

R 09/4

R $07 / 11$

R 09/8

R $16 / 700$

Court Rulings

R 03/1129 (The District Court of Vantaa)

R 04/2483 (Helsinki Court of Appeals)

R 05/3096 (The District Court of Tampere)

R 06/926 (The District Court of Kajaani)

R 07/200 (The Court of Appeals of Eastern Finland)

R 07/3284 (The District Court of Tampere)

R 08/1921 (Turku Court of Appeals)

R 09/3080 (The District Court of Helsinki)

R 09/2786 (Helsinki Court of Appeals)

KKO 2012:58 (The Supreme Court)

R 13/6335 (The District Court of Pirkanmaa)

R 16/2412 (The District Court of Oulu)

R 16/1796 (The District Court of Satakunta)

Other

VKS:2015:4. Menettely sananvapausrikosasioissa. Yleinen ohje. Dnro 21/31/14. 24.4.2015. 


\section{Media Sources}

\section{Brockes, Emma}

2010 'Why are Muslims so hypersensitive?' Interview of Ayaan Hirsi Ali. The Guardian, May 8, 2010. <https://www.theguardian.com/ world/2010/may/08/ayaan-hirsi-ali-interview>, accessed December 9, 2018.

\section{Dawkins, Richard}

2015 A guest appearance in 'Real Time with Bill Maher', HBO (tv-program), aired October 2, 2015. < http://www.real-time-with-bill-maher-blog. com/index/2015/10/3/richard-dawkins-regressive-leftists>, accessed December 18, 2018.

\section{Enbuske, Tuomas}

2015 Message on Twitter.com, September 20, 2015. <https://twitter.com/ TuomasEnbuske/status/645655158517575680>, accessed December 9, 2018.

\section{Halla-aho, Jussi}

2010 Muhammadista ja liberaalista demokratiasta. Blog post on Scripta - Kirjoituksia uppoavasta lännestä, November 4, 2010. <http://www. halla-aho.com/scripta/muhammadista_ja_liberaalista_demokratiasta. html>, accessed December 9, 2018.

\section{References}

\section{Anttonen, Veikko}

2010 Uskontotieteen maastot ja kartat. Helsinki: Finnish Literature Society.

\section{Arminen, Ilkka}

1999 Kirjasodat. - Yrjö Varpio, Pertti Lassila (eds), Suomen kirjallisuushistoria 3: Rintamakirjeistä tietoverkkoihin, 220-26. Helsinki: The Finnish Literature Society.

\section{Äystö, Tuomas}

2017a The Sacred Orders of the Finnish Political Discourse on the Revision of the Blasphemy Law. - Numen 64 (2-3), 294-321.

2017b Blood on a Mosque: Religion and the Sacred and the Finnish Criminal Court Process. - Journal of Religion in Europe 10 (3), 274-300.

2017c Insulting the sacred in a multicultural society: the conviction of Jussi Halla-aho under the Finnish religious insult Section. - Culture and Religion 18 (3), 191-211.

2017d Religious insult and blasphemy in contemporary Finland. - Jeroen Temperman \& András Koltay (eds), Blasphemy and Freedom of Expression: Comparative, Theoretical and Historical Reflections after the Charlie Hebdo Massacre, 317-38. Cambridge: Cambridge University Press. 


\section{Beckford, James}

2003 Social Theory and Religion. Cambridge: Cambridge University Press.

\section{Blevins, Ethan}

2016 A Fixed Meaning of "Religion" in the First Amendment. Willamette Law Review 53 (1): 1-32.

\section{Casanova, José}

1994 Public Religions in the Modern World. Chicago and London: The University of Chicago Press.

\section{Conley, Vial}

2005 Just Words: Law, Language and Power. Chicago and London: The University of Chicago Press.

\section{Crenshaw, Kimberlé}

1991 Mapping the Margins: Intersectionality, Identity Politics, and Violence Against Women of Color. - Stanford Law Review 43 (6), 1241-99.

Day, Abby

2011 Believing in Belonging: Belief and Social Identity in the Modern World. New York: Oxford University Press.

\section{Doe, Norman}

2011 Law and Religion in Europe: A Comparative Introduction. Oxford: Oxford University Press.

\section{Gunn, T. Jeremy}

2003 The Complexity of Religion and the Definition of "Religion" in International Law. Harvard Human Rights Journal 16 (1): 189-216.

Hall, Stuart

1992 The West and the Rest: Discourse and Power. In Bram Gieben and Stuart Hall (eds), The Formations of Modernity, 275-332. Cambridge: Polity Press.

\section{Hall, Stuart}

1997 Introduction. Who needs ‘Identity’? -Stuart Hall (ed.), Representation: Cultural Representations and Signifying Practices, 1-12. London: Sage.

\section{Halme, Miia}

2007 Laki ja ihmisoikeudet - etnografinen lähestymistapa. Oikeus 36 (1): 32-43.

Henttonen, Sini \& Tero Kivinen \& Tapio Rasila \& Johanna Sammalmaa \& Jonna Vihavainen

2015 Kommentaari. - Riku Neuvonen (ed.), Vihapuhe Suomessa, 15-135. Helsinki: Edita.

Hjelm, Titus \& Essi Mäkelä \& Jussi Sohlberg

2018 What do we talk about when we talk about legitimate religion? 
Failure and success in the registration of two Pagan communities in Finland. In George D. Chryssides (ed.): Minority Religions in Europe and the Middle East: Mapping and Monitoring. New York: Routledge University Press.

\section{Hjelm, Titus}

2014 National Piety: Religious Equality, Freedom of Religion, and National Identity in Finnish Political Discourse. - Religion 44 (1): 28-45.

Hokka, Jenni; \& Katja Valaskivi \& Johanna Sumiala \& Suvi Laakso

2013 Suomalaiset sanomalehdet uskonnollisen maiseman tuottajina: Uskontojournalismi Helsingin Sanomissa, Ilkassa, Kalevassa ja Karjalaisessa vuosina 2007-2011. Media E Viestintä 36 (2), 6-21.

\section{Hughes, Aaron W.}

2017 What is the future of religion? - Aaron W. Hughes \& Russell T. McCutcheon (eds): Religion in Five Minutes. Sheffield and Bristol: Equinox.

\section{Illman, Mika}

2005 Hets mot folkgrupp. Helsinki: Suomalainen lakimiesyhdistys.

\section{Gozdecka, Dorota A.}

2009 Religions and Legal Boundaries of Democracy in Europe. European Commitment to Democratic Principles. Helsinki: Faculty of Law, University of Helsinki.

\section{Kainulainen, Heini}

2015 Poliisit ja rosvot. Salaisen tiedon jäljillä. In Antti Häkkinen \& Mikko Salasuo (eds), Salattu, hävetty, vaiettu. Miten tutkia piilossa olevia ilmiöitä, 51-80. Tampere: Vastapaino.

Kaya, Ayhan

2009 Islam, Migration and Integration: The Age of Securitization. New York: Palgrave Macmillan.

\section{Keskinen, Suvi}

2012 Sananvapauden vaatimuksia ja rodullistavaa puhetta - tanskalaisen ja suomalaisen maahanmuuttokeskustelun risteyskohtia. - Oikeus 2012 (2), 287-94.

2013 Antifeminism and white identity politics: Political antagonisms in radical right-wing populist and anti-immigration rhetoric in Finland. Nordic Journal of Migration Research 3 (4), 225-32.

2014 Re-constructing the peaceful nation: negotiating meanings of whiteness, immigration and Islam after a shopping mall shooting. - Social Identities. Journal for the Study of Race, Nation and Culture 20 (6), 471-85.

\section{Ketola, Mikko}

1995 Vapaa Ajatus -lehti suomalaisen jumalanpilkan edistäjänä 1910-1917. - Suomen kirkkohistoriallisen seuran vuosikirja 84-5, 127-72. 


\section{Kolehmainen, Simo}

2009 Syyteoikeudesta sananvapausrikoksissa. Helsinki: Edita.

\section{Koltay, András \& Jeroen Temperman}

2017 Introduction. - András Koltay \& Jeroen Temperman (eds), Blasphemy and Freedom of Expression. Comparative, Theoretical and Historical Reflections after the Charlie Hebdo Massacre, 1-23. Cambridge: Cambridge University Press.

\section{Koski, Aleksi}

2011 Tietopyyntöjen yhteinen sävel. - Heikki Kuutti (ed.), Julkisuusjournalismi, 382-395. Jyväskylä: Deparment of Communication Studies, University of Jyväskylä.

\section{Lappi-Seppälä, Tapio}

2000 Rikosten seuraamukset. Porvoo: WSOY.

\section{Lepola, Outi}

2000 Ulkomaalaisesta suomenmaalaiseksi. Monikulttuurisuus, kansalaisuus ja suomalaisuus 1990-luvun maahanmuuttopoliittisessa keskustelussa. Helsinki: Finnish Literature Society.

\section{Martikainen, Tuomas}

2008 Muslimit suomalaisessa yhteiskunnassa. - Tuomas Martikainen, Tuula Sakaranaho, Marko Juntunen (eds), Islam Suomessa. Muslimit arjessa, mediassa ja yhteiskunnassa, 62-84. Helsinki: Finnish Literature Society.

2013a Uskonnon hallinta ja turvallistaminen valtiollisena toimintana. - Tuomas Martikainen ja Marja Tiilikainen (eds), Islam, hallinta ja turvallisuus, 253-77. Turku: Eetos.

2013b Religion, Migration, Settlement: Reflections on Post-1990 Immigration to Finland. Leiden: Brill.

\section{Miles, Robert \& Malcom Brown}

2003 Racism. London and New York: Routledge.

\section{Moberg, Marcus \& Måns Broo \& Janne Kontala \& Peter Nynäs}

2015 Contemporary Discursive Formations. - Peter Nynäs, Ruth Illman \& Tuomas Martikainen (eds), On the Outskirts of 'the Church': Diversities, Fluidities and New Spaces of Religion in Finland, 55-72. Berlin: Lit Verlag.

\section{Moberg, Marcus}

2013 First-, second-, and third-level discourse analytic approaches in the study of religion: moving from meta-theoretical reflection to implementation in practice. Religion 43 (1): 4-25.

\section{Nagel, Joane}

2003 Race, Ethnicity, and Sexuality. Intimate Intersections, Forbidden Frontiers. New York: Oxford University Press. 


\section{Neuvonen, Riku}

2012 Sananvapauden sääntely Suomessa. Helsinki: The Association of Finnish Lawyers.

\section{Niemelä, Kati \& Henrik Reintoft Christensen}

2013 Religion in the Newspapers in the Nordic Countries in 1988-2008. Nordic Journal of Religion and Society 26 (1), 5-24.

\section{Nongbri, Brent}

2013 Before Religion: A History of a Modern Concept. New Haven and London: Yale University Press.

\section{Nye, Malory}

2001 Multiculturalism and Minority Religions in Britain: Krishna Consciousness, Religious Freedom, and the Politics of Location. Richmond: Curzon Press.

2018 Race and Religion: Postcolonial Formations of Power and Whiteness. Method and Theory in the Study of Religion. Doi: 10.1163/1570068212341444

\section{Olli, Soili-Maria}

2008 Blasphemy in Early Modern Sweden - An Untold Story. - Journal of Religious History 32 (4), 457-70.

\section{Owen, Suzanne \& Teemu Taira}

2015 The Category of 'Religion' in Public Classification: Charity Registration of the Druid Network in England and Wales. - Trevor Stack, Naomi Goldenberg \& Timothy Fitzgerald (eds), Religion as a Category of Governance and Sovereignty. Leiden: Brill, 90-114.

\section{Pauha, Teemu \& Suaad Onniselkä \& Abbas Bahmanpour}

2017 Kaksi vuosisataa suomalaista islamia. - Ruth Illman, Kimmo Ketola, Riitta Latvio ja Jussi Sohlberg (eds), Monien uskontojen ja katsomusten Suomi, 104-15. Tampere: The Church Research Institute.

\section{Puuronen, Vesa}

2011 Rasistinen Suomi. Helsinki: Gaudeamus, Helsinki University Press.

\section{Richardson, James $\mathrm{T}$.}

2000 Discretion and Discrimination in Legal Cases involving Controversial Religious Groups and Allegations of Ritual Abuse. - Rex Adhar (ed.), Law and Religion, 111-32. Aldershot: Ashgate.

\section{Robertson, Teresa \& Philip Atkins}

2018 Essential vs. Accidental Properties. In Edward N. Zalta (ed.): The Stanford Encyclopedia of Philosophy (Spring 2018 Edition). <https:// plato.stanford.edu/archives/spr2018/entries/essential-accidental/>. 


\section{Ruuskanen, Minna}

2006 Tuomioistuinratkaisut diskurssianalyysin kohteena. - Johanna NiemiKiesiläinen, Päivi Honkatukia, Helena Karma \& Minna Ruuskanen (eds): Oikeuden tekstit diskursseina, 43-60. Helsinki: Suomalainen lakimiesyhdistys.

\section{Saarela, Anna}

2011 Uskonnollisten loukkausten kriminalisointi erityisesti sananvapauden näkökulmasta. - Helsinki Law Review 2011 (1): 37-64.

\section{Seikkula, Minna}

2015 Rodullistavien rajanvetojen kyseenalaistaminen rasismin kohteeksi joutuvien blogiteksteissä. - Sukupuolentutkimus - Genusforskning 28 (4): 20-31.

Smith, Jonathan Z.

2004 Relating Religion: Essays in the Study of Religion. Chicago and London: The University of Chicago Press.

\section{Stuckrad, Kocku von \& Frans Wijsen}

2016 Introduction. In Frans Wijsen \& Kocku von Stuckrad (eds): Making Religion: Theory and Practice in the Discursive Study of Religion. Leiden \& Boston: Brill.

\section{Sutela, Mika}

2016 Arbitrium an decisio - Oikeudellisen päätöksenteon yhtenäisyys yleisissä tuomioistuimissa. Joensuu: University of Eastern Finland.

\section{Taira, Teemu}

2006 Notkea uskonto. Turku: Eetos.

2010 Religion as a Discursive Technique: The Politics of Classifying Wicca. - Journal of Contemporary Religion 25 (3): 379-94.

2013 Making Space for Discursive Study in Religious Studies. - Religion 43 (1): 26-45.

2015 Pehmeitä kumouksia. Uskonto, media, nykyaika. Turku: Eetos.

2016 Discourse on 'Religion' in Organizing Social Practices: Theoretical and Practical Considerations. - Frans Wijsen \& Kocku von Stuckrad (eds), Making Religion: Theory and Practice in the Discursive Study of Religion, 125-46. Leiden: Brill.

\section{Toivanen, Mari}

2014 The Visual Lexica of (National) Belonging and Nonbelonging in the Accounts of Young Kurds in Finland. - Nordic Journal of Migration Research 4 (4), 192-200.

Vial, Theodore

2016 Modern Religion: Modern Race. Oxford: Oxford University Press.

Wijsen, Frank

2013 Editorial: discourse analysis in religious studies. Religion 43 (1): 1-3. 